\title{
İ. İ. Sreznevskiy ve Rus sözlükbiliminin ilk tarihsel sözlüğï
}

\section{Ümmügülsüm DOHMAN'}

\begin{abstract}
APA: Dohman, Ü. (2019). İ. İ. Sreznevskiy ve Rus sözlükbiliminin ilk tarihsel sözlüğü. RumeliDE Dil ve Edebiyat Araştırmaları Dergisi, (17), 451-460. DOI: 10.2900o/rumelide.657924
\end{abstract}

\section{$\ddot{O} \mathbf{z}$}

Çalışmalarının odak noktasını dil ve halk olarak belirleyen İzmail İvanoviç Sreznevskiy (1812-1880) XIX. yüzyıl Rusya'sının ilk Slavist bilim insanıdır. Rus dili tarihi, diyalektoloji, sözlükbilim, paleografi gibi çeşitli bilim alanları üzerinde çalışmalarda bulunmuştur. İ. İ. Sreznevskiy 1839-1842 yılları arasında Milli Eğitim Bakanlı̆̆ı tarafından Slav halkları, dilleri ve lehçeleri üzerine inceleme yapması için Batı Slav topraklarına gönderilmiştir. Burada Slav halklarının dilleri, lehçeleri, edebiyatları ve kültürleri üzerine çalışmalar yapmakla birlikte eski yazılı eserlerin araştırılması ve okunmasıyla ilgilenerek Rus sözlükbiliminin ilk tarihsel sözlüğü unvanını alacak olan Yazılı Eserler Temelinde Eski Rusçanın Sözlüğü İçin Malzemeler (Materialı dlya slovarya drevnerusskogo yazıka po pismennım pamyatnikam) adlı eserine kaynak toplamaya başlamıştır. İ. İ. Sreznevskiy’in üzerinde yaklaşık 40 yıl titizlikle çalıştı̆̆ı sözlüğü ne yazık ki kendisinin ölümünden sonra 1893 - 1912 yılları arasında üç cilt olarak yayımlanmıştır. Sözlüğün hacmini o döneme kadar orijinali ya da kopyası korunmuş yazılı eserler, tüzük ve antlaşma gibi her türlü belge oluşturmaktadır. Tarihsel sözlükbilim çalışmaları açısından oldukça değerli olan bu sözlükte Rus halkının maddi ve manevi yaşamı, tarihî ve milli kültürel ögeleri yer almaktadır. Bu bağlamda sözlük kültürdilbilimsel özellikler de taşımaktadır. Bu çalışmada İ. İ. Sreznevskiy’in şahsiyeti, bilimsel çalışmaları ve sözlükbilime olan katkıları incelenecektir. Bununla birlikte Sreznevskiy'in Yazıl Eserler Temelinde Eski Rusçanın Sözlüğü İçin Malzemeler adlı eseri özellikle sözlükteki Türkçe kökenli madde başlarından örnekler verilerek değerlendirilecek, bilimsel çalışmalarının yönü ve hazırladığı sözlük için belirlediği ilkeler ortaya konulacaktır.

Anahtar kelimeler: İ. İ. Sreznevskiy, sözlükbilim, dil tarihi, Slavist, Türkoloji.

\section{I. Sreznevskiy and the first historical dictionary of Russian lexicography}

\begin{abstract}
Izmail Ivanoviç Sreznevsky (1812-1880), who established the focus of his studies as language and people, was the first Slavist scientist of the 19th century Russia. He conducted studies on various scientific fields such as the history of the Russian language, dialectology, lexicography, and paleography. I. I. Sreznevsky was sent to the Western Slavic lands between the years of 1839 and 1842 by the Ministry of National Education to carry out researches on Slavic people, their languages and dialects. There, he carried out research studies on the languages, dialects, literature and culture of Slavic people, and started to collect resources for his study named Materials for the Dictionary of the Old Russian on the Basis of Written Records (Materialı dlya slovarya drevnerusskogo yazıka po pismennım pamyatnikam), which would later be titled as the first historical dictionary of Russian lexicography, by researching and reading ancient written works. Unfortunately, İ. İ. Sreznevsky's
\end{abstract}

1 Öğr. Gör., Trakya Üniversitesi, Edebiyat Fakültesi, Mütercim-Tercümanllk Bölümü (İngilizce) (Edirne, Türkiye), ugulsumdohman@trakya.edu.tr, ORCID ID: 0000-0003-3713-7521 [Makale kaylt tarihi: 10.10.2019-kabul tarihi: 20.12.2019; DOI: 10.29000/rumelide.657924] 
dictionary, on which he worked meticulously for approximately 40 years, was published after his death between the years of 1893 and 1912 in three volumes. The dictionary consists of all kinds of documents such as written works, statutes and treaties whose original versions or copies had been preserved until that period. In this dictionary, which is significantly valuable in terms of historical lexicography studies, includes the material and spiritual life, history and national cultural elements of Russian people. In this context, the dictionary has features of cultural linguistics. In this study, I. I. Sreznevsky's personality, scientific studies and contributions to lexicography will be examined. In addition, İ. İ. Sreznevsky's study named Materials for the Dictionary of the Old Russian on the Basis of Written Records will be evaluated especially by giving examples from the headings of Turkish origin in the dictionary and the direction of his scientific studies and the principles which he set for his dictionary will be put forward.

Keywords: I. I. Sreznevsky, lexicography, history of languages, Slavist, Turcology.

\section{Giriş}

Tarihsel sözlükler V. V. Dubiçinskiy, (2009: 202), E. G. Şimçuk, (2009: 171), L. P. Krısin, (2009: 224) gibi bilim insanlarının çalışmalarında eski dönem yazılı eserlerinde kullanılan sözcüklerin açıklanmasını içeren sözlük türleri olarak tanımlanmaktadır. Rusya'da kadim dönem yazılı eserlerinde geçen sözcüklerin tanımlandığı kelime listeleri XI. yüzyıldan itibaren hazırlanmış olsa da tarihsel sözlüklerin bir tür olarak ortaya çıkışı XIX. yüzyıla denk gelmektedir (Dubiçinskiy, 2009: 202-203). Bu bağlamda İzmail İvanoviç Sreznevskiy (1812-1880) yaptığı dil-tarihi çalışmalarının yanı sıra hazırlamış olduğu Yazılı Eserler Temelinde Eski Rusçanın Sözlüğü Iç̧in Malzemeler (1893-1912) (Materialı dlya slovarya drevnerusskogo yazıka po pismennım pamyatnikam) adlı sözlüğüyle Rus dili tarihinin ve tarihsel sözlükbilimin kurucusu olarak önemli rol oynamaktadır.

XIX. yüzyıl dilbilimi ve sözlükbilimine büyük katkılar sağlayan İ. İ. Sreznevskiy (1812-1880) Rusya'nın ilk Slavist bilim insanıdır. 1839-1842 yılları arasında Milli Eğitim Bakanlığı tarafından Slav halkları, dilleri ve lehçeleri üzerine inceleme yapmak üzere Batı Slav topraklarına gönderilen İ. ̇̇. Sreznevskiy, 1840’lı yıllardan itibaren eski yazılı eserlerin araştırılmasına ve okunmasına yönelmiştir. Eski yazılı eserler ait olduğu halkın dilini, tarihini, kültürünü sunan ilk kaynaklar olduğu için bu alan üzerine yoğunlaşan Sreznevskiy, Rus dili tarihinin incelenmesiyle ilgili çalışmaların da yolunu açmıştır. Bununla birlikte diyalektoloji, paleografi, sözlükbilim gibi birçok alan üzerinde çalışmalar yapmıştır. Eserlerinin ve çalışmalarının tümü değerli olmakla birlikte özellikle Rus Dili Tarihi Üzerine Düşünceler (1887) (Mıslı ob istorii russkogo yazıka) ve Yazıl Eserler Temelinde Eski Rusçanın Sözlüğü İçin Malzemeler (1893-1912) adlı eserleriyle ön plana çıkmaktadır. Bu çalışmada da Sreznevskiy’in Rus sözlükbilim geleneğinin ilk tarihsel sözlüğü unvanını alan Yazıl Eserler Temelinde Eski Rusçanın Sözlüğ̈̈ İçin Malzemeler sözlüğü üzerinde durulacaktır.

\section{2. İ. İ. Sreznevskiy'in aile ve eğitim hayatı}

İ. İ. Sreznevskiy, 1812 yılında Moskova'nın kuzeyinde bulunan Yaroslavl'da dünyaya gelmiştir. Eğitimiyle yakından ilgilenen babasını daha 7 yaşındayken kaybeden Sreznevskiy, annesi Elena İvanovna tarafından büyütülmüştür. İlkokul ve ortaokul eğitimini özel yatılı bir okulda almış, 1826 yılında 14 yaşındayken Harkov Üniversitesi’nin (Ukrayna), Siyasi Bilimler Bölümüne girmiş, 1829 yllında buradan mezun olmuştur. 1835 yılında yine Harkov Üniversitesi’nin Siyasi Bilimler Bölümünde yüksek lisansa başlamıştır. 1837 yılında yüksek lisansını tamamlayıp, doktoraya devam etmiştir. 
Doktora tez savunmasında aldığı olumsuz görüşler, onun erken yaşlardan itibaren Slav dillerine ve edebiyatına olan ilgisini uyandırmıştır. Siyaset bilimi alanında doktor unvanını almaya ramak kalmışken alan değiştirmek elbette kolay olmamıştır. Bununla birlikte filolojiye, edebiyata olan ilgisi de yeni bir şey değildir. Harkov Üniversitesi’nin Kadim Dillerin Yazılı ve Sözlü Edebiyatı Bölümünün başkanı, retorik Profesörü olan babası İvan Yevseyeviç Sreznevskiy edebiyat sevgisini büyük oğlu İ. ̇̇. Sreznevskiy'e çok erken yaşlarda aşılamıştır. Edebiyatla, etnografyayla öğrencilik yıllarından beri ilgili olan Sreznevskiy'in 1830'lu yıllardan itibaren bazı dergilerde yazıları, şiirleri çıkmıştır. Mesela, Ukrainskiy Almanah adlı dergide birkaç şiiri yayımlanmıştır. Karar verme aşamasında olan İ. İ. Sreznevskiy'e bu dönemde Slav ülkelerinde staj yapma teklifi gelince kararı netleşmiş ve böylece siyaset bilimi uzmanlığından, Slavist olmaya doğru yön değıştiren çalışma alanının ön safhası başlamıştır.

İ. İ. Sreznevskiy 1844 yılında Yekaterina Fedorovna Tyurina ile Harkov'da evlenmiştir. Bu evlilikten 4 oğlu 4 kızı olmuştur. Çocuklarının eğitimiyle ve gelişimiyle yakından ilgilenen Sreznevskiy, edebiyat, sanat, bilim, beden eğitimi gibi birçok ilgi alanına sahip olması sayesinde çocuklarına ev eğitimi vermiştir. Onlar da babaları gibi 14 yaşında üniversiteye girmişlerdir. Sreznevskiy, bir çocuğun başarılı bir şekilde yetişmesinde ahlaki, fiziki ve akıl gelişimi olmak üzere üç noktaya önem vermiş, çocuklarının eğitimini de bu üç husus temelinde yönlendirmiştir (Kolguşkina, 2017: 106-111). Bu bağlamda çocukları hukuktan ekonomiye, mühendislikten doktorluğa, ressamlıktan şarkıcılığa, çevirmenlikten tarihçiliğe farklı alanlarda uzmanlaşmışlardır. Çocukları arasında özellikle kızı Olga İzmailovna Sreznevskaya (1845 - 1931) ve oğlu Vyaçeslav İzmayloviç Sreznevskiy (1849-1935) diğerlerinden ayrı bir öneme sahiptir, çünkü babalarının yarım kalan çalışmalarının devam ettirilmesinde etkin rol oynamışlardır. Olga, kadim sözlüklerin çevirisini yapan, yazar, çevirmen ve filologdur. Vyaçeslav erken yaşlardan itibaren babasının çalışmalarına yardım etmiş, yazılı eserlerin korunmasına önem verdiği için sabırla ve titizlikle onların kopyasını çıkarmış ve fotoğrafını çekmiştir. Dil-Tarih Fakültesi mezunu olan Vyaçeslav 1877 yılında babası ölmeden 3 yl önce Slav filolojisi üzerine yaptığı yüksek lisans tezini savunmuştur. Tarih, edebiyat, arkeoloji alanlarıyla ilgilenen Vyaçeslav, babasının yarım kalan çalışmalarını devam ettirmiştir.

\section{3. İ. İ. Sreznevskiy'in saha araştırmaları ve çalışmaları}

İ. İ. Sreznevskiy, 1839 yılında Milli Eğitim Bakanlığı tarafından Harkov Üniversitesi’nin Slav Lehçeleri ve Edebiyat Tarihi Bölümünün derslerini hazırlaması amacıyla anlaşmalı olarak Batı Slav topraklarına gönderilmiştir. 1839 yllından 1842 yllına kadar Sreznevskiy, Çek Cumhuriyeti, Polonya, Surbistan, Hırvatistan, Avusturya ve Almanya gibi çeşitli ülkelerde yaşayarak saha araştırmalarında bulunmuştur. Berlin'de ve Bonn'da Sanskritçeyle ilgilenen bilim insanı, Almanya'da "resmi azınlık" statüsündeki bir Batı Slav halkı olan Sorbların dilini incelemiş, Sorbça sözlük hazırlamak için çalışmıştır. Sreznevskiy, Slav topraklarıyla tanıştıkça, Slav nüfusunun haritasını çıkarmış, Slav dili, edebiyatı ve kültürü üzerine araştırmalar yapmıştır (Bogatova, 2011: 128-129). 1839-1842 yılları arasında Sreznevskiy'in saha gezilerinden edindiği deneyimleri, gözlemleri 1895 yılında Bilimler Akademisi tarafından $\dot{I}$. $\dot{I}$. Sreznevskiy’in Slav Topraklarndan Gönderdiği Gezi Mektupları (1839-1842) (Puteviye pisma İzmaila İvanoviça Sreznevskogo iz slavyanskih zemel 1839-1842) adıyla yayımlanmıştır. Adı geçen çalışma, dönemin kültürünü, dilini, değerlerini yansıtmakta olup aynı zamanda Sreznevskiy'in hayatından kesitler sunmaktadır. Bu çalışmada Sreznevskiy'in gezi sırasında çektiği zorluklar annesi E. İ. Sreznevskaya’ya gönderdiği mektuplardan anlaşılmaktadır. Misal 30 Eylül 1839 tarihinde kaleme aldığı mektubunda satırları üzüntüyle yazdığını annesine bildirmektedir. Gece yarısından öğlen ikiye kadar istasyonda oturarak at beklediğini ama atın bir türlü gelmediğini ve ne yapacağını bilemediğini, atı beklerken ruhunu iyileştirmek için annesine yazdığını ifade etmektedir (Sreznevskiy, 1895: 8). Bu 
mektuplardan Sreznevskiy’in annesiyle arasındaki bağın ne kadar derin ve özel olduğu, kullandığı sevgi sözcüklerinden, özlemini ifade ettiği cümlelerden anlaşılmaktadır. Örneğin ilk mektubunda annesine "Benim tatl, iyi kalpli anneciğim elinizi bir kez daha öpebilmeyi ne kadar da çok isterdim. Ama kader uzun süreliğine bizi ayırdı... Benim tatl anneciğim" (Sreznevskiy, 1895: 1) diye seslenmektedir. Başka bir mektubunda annesinden mektup beklemenin hüzün verici olduğunu, ondan daha sık mektup yazmasını istediğini ve mektubu okurken sevinçten ağladığını yazmaktadır. Bir diğer mektubunda ise annesinin mektubu elinde uyuya kaldığından, bir günlüğüne de olsa Harkov’a annesini görmeye gelmek istediğinden bahsetmektedir (Sreznevskiy, 1895: 81).

Sreznevskiy, Dubrovnik seyahatiyle ilgili mektubunda şehirle ilgili gözlemlerini aktarmaktadır. Şehrin sağlam duvarlarla çevrildiğini, duvarların denize kadar indiğini, manzaranın harika göründüğünü, Dubrovnik'in ana sokaklarının geniş ve düz, her yerin temiz olduğunu, en güzel şeyin ise kimi zaman İtalyanca duyulsa da her yerde tanıdık sesler işittiğini belirtmektedir. Hava sıcaklığının 23 derece olduğunu belirten Sreznevskiy, havayı çok sıcak bulduğunu, bu aylarda (temmuz) böyle güney ülkelerine seyahat etmenin iyi olmadığını, Ukrayna'da bu derecelerdeki bir havanın bu kadar sıcak hissedilmediğini ifade etmektedir (Sreznevskiy, 1895: 227). Görüldüğü üzere bu eserde yer alan mektuplar Sreznevskiy’in saha gezilerini anlattı̆̆ yazılardır. Bu mektuplar Slav ülkelerinin fiziki şartlarını, genel görünümünü, dillerini, günlük yaşam ve geleneklerini bir filolog gezginin gözünden sunmaktadır. Böylece İ. I. Sreznevskiy”in Slav Topraklarından Gönderdiği Gezi Mektuplarl (18391842) adlı eseri aracılığıyla bilim insanın sadece ruhsal ve ailevi durumu değil aynı zamanda araştırma yaptığı bölgeler hakkında da bilgi edinilmektedir.

İ. İ. Sreznevskiy, bir ülkenin özelliklerini belirleyebilmek için sadece şehrin merkezine değil nehir ve dağlık alanların bulunduğu bölgelere de gezi düzenlemiştir. Bu gezilerde Sreznevskiy, ülkenin fiziki durumu, iklimi, doğal zenginlikleri, doğal güzellikleri, yerli halkın eğitim seviyesi, endüstrinin gelişimi vb. hususlarının hepsine önem vermekte, bu hususların o halkın özelliklerini belirlediğini düşünmektedir. Her halkın diyalektolojik özelliklerini inceleyen bilim insanı, kışın şehirlerde kalıp kendisinin topladığı ve ona bilim insanları tarafından verilen Slav halkları ile ilgili kaynakları değerlendirmiştir. Ilık geçen diğer mevsimlerde ise çoğunlukla yürüyerek yalnız başına bu ülkeleri gezmiştir. Seyahat ettiği dönem Panslavizm’in çok yaygın olduğu bir dönemdir. Her yerde I. Petro'nun ve Çar Nikolay’ın portreleri asılıdır. Bu nedenle gezdiği yerlerin çoğunda hoşgörüyle karşılanmıştır.

Yurtdışı gezisinden döndükten sonra 1842-1846 yılları arasında Milli Eğitim Bakanlığıyla yaptığı anlaşma gereğince Harkov Üniversitesi'nin Slav Filolojisi Bölümünün başkanlığına getirilmiştir. Burada, "Slav Halklarının Tarihi ve Edebiyatı" (İstoriya i literatura slavyanskih nareçiy) dersini vermiştir. Bu yllarda "Slav filolojisi", "Eski Slavca", "Slav dillerinin ve lehçelerinin Slav halklarıyla olan kültürel ve edebi bağı” adlı dersleri anlatmıştır.

1846 yllında Slavlarm Dini ve Dini Ayinleri Üzerine başlıklı doktora tezini savunarak Rusya'daki ilk Slav Filolojisi Doktoru unvanını almıştır. Güney ve Batı Slavları üzerindeki çalışmaların ardından bir Slavist olarak Eski Rusça yazılı eserlerin incelenmesi konusuna yoğunlaşmıştır (Bogatova, 2011: 129). 1847 yılında Sreznevskiy'e St. Petersburg Üniversitesi tarafından Slav Filolojisi Bölümü başkanlığı teklif edilmiştir. Bilim insanı bu teklifi kabul ederek hayatının son anına kadar yaşayacağı St. Petersburg’a taşınmıştır. Burada yaşama fikri Sreznevskiy’i heyecanlandırmıştır, çünkü şehirdeki kütüphaneler Rus ve Güney Slavlarına ait değerli yazılı eserlere sahiptir. Böylece eski yazılı eserlere ulaşımı kolaylaşacak ve Eski Rusçanın Sözlüğü için malzemeleri toplamaya devam edebilecektir. 
1849 yılının Şubat ayında İ. İ. Sreznevskiy, St. Petersburg Üniversitesi’nin yıllık toplantısında Rus Dili Tarihi Üzerine Düşünceler adlı konuşmasını gerçekleştirmiştir. Sreznevskiy'in bu konuşmasına daha sonra eklemeler yapılarak 1887 yılında Rus Dili Tarihi Hakkında Düşünceler (Mısli ob istorii russkogo yazıka) başlığıyla bilim insanının ölümünden sonra yayımlanmıştır. Bu eserde Sreznevskiy, çeşitli sorular sorarak Rus dilinin ve milletinin tarihini araştırmaktadır. Misal, Sreznevskiy, dil tarihinin halkın tarihiyle birlikte incelenmesi gerektiğini şu cümlelerle belirtmektedir: "Dil, tüm halkn bölünmez bir bütünüdür. İnsandan insana, kuşaktan kuşağa aktarllır. <...> Halk bilimi araştırmalart içerisinde yer alan dilin, tarihi yön olmadan incelenmesi imkânsızdır. Dil tarihi halkın tarihiyle yakından ilgilidir" (Sreznevskiy, 1887: 2-3). Sreznevskiy, Rus dili tarihinin incelenmesine sevk ettiği bu çalışmasında, Kadim Rusçanın kullanıldığı dönemin belirsizlik içerdiğini, ancak bu döneme ait Rusçanın geleneklerde, kültürde, bir arada yaşadığı kabilelerle olan iletişiminde, yazışmalarında ortaya çıkacağını, hiçbir şeyin yok olamayacağını ifade etmektedir (Sreznevskiy, 1887: 17). Dolayısıyla kadim yazılı kaynaklarda her şeyin bulunabileceğini, Rusçayla ilgili belirsizlikleri ortadan kaldırabilmek için kadim dönem Rus diline ait her türlü kaynağın dil ve halk ekseninde incelenmesi gerektiğini vurgulamıştır.

İ. İ. Sreznevskiy'in 1853-1866 yılları arasında Eski Rusça yazılı eserlerin incelemesini yaptığı çalışmaları 1903 ylında Bilimler Akademisi tarafından İ. I. Sreznevskiy’in Eski Rusça Elyazmaları Üzerine Makaleler (Stati o drevnih ruskih letopisyah İ. İ. Sreznevskogo (1853-1866) başlı̆̆ıyla yayımlanmıştır (Sreznevskiy, 1903). Bu çalışmanın ilk bölümünü "Novgorod El Yazmaları Üzerine Araştırmalar” adlı makale oluştururken, ikinci bölüm "Eski Rusya El Yazmaları Üzerine Okumalar” derlemelerini içermektedir. İkinci bölümde yer alan bu yazılar Rusya'da X. Yüzyılda El Yazmaları Var Mıydı? (Bıli li na Rusi letopisi X veke?), X. Yüzyıl Rus Elyazmalarının İçeriği (Soderjaniye russkih letopisey X. veka), X. Yüzyıl Elyazmaları Hikâyelerinde Rus Halkının Gündelik Yaşamını Özellikleri (Çertı bita russkogo naroda po letopisnım skazaniyam X. veka) adlı çalışmalardan ve Geçmiş Yılların Hikâyesi (Povest vremennıh let) adlı eserden oluşmaktadır. Çalışmadaki son okuma olan Geçmiş Yılların Hikâyesìnde bu eserin içeriği, dili ve ne zaman yazıldı̆̆ıyla ilgili sorunlar irdelenmektedir.

\section{4. İ. İ. Sreznevskiy’in Yazılı Eserler Temelinde Eski Rusçanm Sözlü̆̆̈̈̈ İçin Malzemeler adlı sözlüğü}

Dil tarihine, eski Rusça el yazmalarına büyük ilgi duyan İ. İ. Sreznevskiy, eski Rusçanın söz varlı̆̆ıyla ilgili kelimeleri 1840'lı yllardan itibaren toplamaya ve incelemeye başlamış, bu kaynaklar temelinde bazı kısa sözlükler oluşturmuş̧tur. Örneğin, Vladimir Monomah’n Öğretisi’nin ve ilk Kiev prenslerinin Yunanlılarla yaptıkları antlaşma metinlerinin kısa sözlüğünü hazırlamıştır. St. Petersburg’a taşındığı ilk ylddan itibaren düzenli olarak farklı sözlük değerlendirmeleri yapmıştır. 1847 yllında Akademi Sözlüğü, 1848 yılında F. Reyfin sözlükleri, 1852 yılında Nesselman’ın Litvanca Sözlüğ̈̈u, 1854 yllında A. Afanesyev'in Malorusskiy (Ukrayna) Lehçesi Sözlüğü, 1847 yllında A. H. Vostokov'un Kilise Slav Dili Sözlüğü üzerine çeşitli sözlük değerlendirmeleri ve diğer pek çok makale yayımlamıştır (Bogatova, 2011: 131). Dolayısıyla kendi sözlüğünü yayımlamadan önce birçok sözlük çalışmasında yer almıştır.

İ. İ. Sreznevskiy, Yazılı Eserler Temelinde Eski Rusçanın Sözlüğü İçin Malzemeler (Materialı dlya slovarya drevnerusskogo yazıka po pismennım pamyatnikam) adlı eseri üzerinde yaklaşı 40 yıl (18401879) çalışmıştır. Sreznevskiy bu sözlük için XI. yüzyıldan XVIII. yüzyıla kadar gelen eski yazılı eserlere ait orijinalini ya da kopyasını ayırt etmeksizin vakayinameler, mektuplar, tüzükler, antlaşmalar, notlar, sözcükler, efsaneler, din adamlarının yaşamı gibi her türlü kaynağı incelemiş ve sözlüğün kartoteğini hazırlamıştır. Sreznevskiy, 1866 yllında sözlüğün planını neredeyse belirlemiştir. Bu plana göre: 
1. XI. yüzylldan başlayarak XVIII. yüzyıla kadar korunan Eski Rusça kaynakların orijinallerinde ve kopyalarında yer alan sözcükler taranmış ve sözlüğün hacmi oluşturulmuştur. Hazırlanan bu söz varlığı “Eski Rusça Eserlerin Sözlüğü” ve “Önceki Dönemlere Ait Eserlere İşaret Eden Rusça Sözlük” olarak ikiye ayrılmıştır.

2. XI. ve XVI. yüzyıllara ait eserlerde karşılaşılan her sözcük sözlükte yer almalıdır. XV. ve XVIII. yüzyıla ait eserlerde bulunan sözcüklerden, çoğunlukla bugün de kullanılan sözcüklerin açıklanması için yararlanılmalıdır.

3. Sözcüğün anlamının belirlenmesinde taranılan kaynaklarda bir sözcükle birçok kez karşılaşılıyorsa hangi anlamı daha net ise o seçilmeli, birden fazla anlamı varsa eserden alıntılar yapılarak farklı anlamları gösterilmelidir (Sreznevskiy, 1893: III-IV).

İ. İ. Sreznevskiy, bu sözlük için 2700 Eski Rusça eser incelemiş ve yaklaşık 210 adet farklı Rusça belge türü hakkında bilgi vermiştir (Golovina, 2007: 194). Sreznevskiy, bu kadar zengin malzeme üzerinde çalışınca sözlüğün planını hazırlamakta zorluk çekmiştir. Özellikle Eski Rusça ve Kilise Slav Dili adı verilen dilleri birbirinden ayırt etmenin oldukça zor olduğunu açıklamıştır. Bu durumu şuan sözde, kitaplarda, resmi yazışmalarda kullanılan Rusçayı, halkın konuştuğu Rusçadan ayırmak gibi bir şey olarak açıklamaktadır. Bu sebeple Sreznevskiy, Rusça yazılı eserlerdeki tüm sözcüklerin sözlükte yer alması gerektiği sonucuna varmıştır (Bogatova, 2011: 133). Bu bilgiler doğrultusunda bilim insanı birbirine çok benzeyen iki dilin başka bir deyişle edebi dil ile konuşma dili gibi çok yakın olan iki dili birbirinden ayırmak gibi zor bir görevle karşılaşmıştır.

Sözlüğün üzerinde uzun yllar titizlikle ve özenle çalışan İ. İ. Sreznevskiy, 1866 yllında sözlüğün basımıyla ilgili ilk hazırlıkları yapmıştır. Biliminsanı, sözlüğün basılan ilk cildinde bulduğu bazı eksik verilerden dolayı basımı durdurmuştur. Sözlüğün basım aşamasında eski eserlere ait yeni kaynaklar bulan Sreznevskiy, onların da sözlüğe dâhil edilmesi gerektiğini düşünmüştür. Dolayısıyla sözlüğün yayımlanma süreci ertelenmiştir. Ne yazık ki, Sreznevskiy 1880 yılında sözlüğü yayımlayamadan hayata veda etmiştir. Rus Dili Bölümü ve Bilimler Akademisi Yazılı ve Sözlü Eserler Bölümü, Sreznevskiy’in çalışmalarının yakın tanığı olan kızı Olga İzmailovna Sreznevskaya'dan ve oğlu Vyaçeslav İzmayloviç Sreznevskiy'den sözlüğün tamamlanabilmesi için yardım istemiştir. Böylece, sözlük, oğlunun ve kızının desteğiyle Sreznevskiy’in hazırladığı şekilde Yazılı Eserler Temelinde Eski Rusçanın Sözlüğü İçin Malzemeler (Materialı dlya slovarya drevnerusskogo yazıka po pismennım pamyatnikam) başlığıyla 1893 yılında üç cilt olarak yayımlanmıştır. Yayına hazırlanma aşaması tarihçi, editör, kütüphaneci, yayınevi sahibi A. F. Bıçkov (1818-1899) ve dil tarihçisi A. A. Şahmatov'un (1864-1920) gözetiminde gerçekleştirilmiştir.

Sreznevskiy'in sözlüğünün genel özelliklerine bakılacak olursa eserde yaklaşık 40.000 sözlük maddesi bulunmaktadır. Madde başlarının diziminde alfabetik yöntem kullanılmıştır. Sözlükte yer alan madde başlarının anlamları açıklanmış, hangi kaynaklarda geçtiği kronolojik olarak belirtilmiştir. Anlamlar genellikle Rusça açıklanmış, bazı durumlarda sözcüklerin Latince ve Yunanca karşılıklarına başvurulmuştur. Bununla birlikte bu sözlükte Türk halklarının dili, maddi ve manevi yaşamı yansıtılmaktadır. Çünkü Sreznevskiy’in sözlüğünde Türk kökenli sözcükler de sunulmaktadır. Örneğin Rus dilinin etimolojik sözlüğünü hazırlayan M. Fasmer’in (1886, 71) de belirttiği üzere Teleütçe, Tatarca, Kazakça, Kırgızca, Kıpçakça gibi Türk dilleri lehçelerindeki "elmas" anlamına gelen алмазь - almaz madde başı Rusçaya geçerek Sreznevskiy'in sözlüğünde yer bulmuştur. Burada Rusça bir kelimenin "z" harfi ile bittiğinde "s" olarak okunduğunu belirtmekte fayda vardır. Bu bağlamda "almaz" olarak yazılan 
sözcüğün telaffuzu “almas”tır. Sözlükte "elmas” sözcüğünün “değerli bir taş olduğu, kayalıkh dağlarda oluştuğu ve 2000 funt altın değerinde olduğu” açıllanmaktadır. Bununla birlikte bu sözcü̆ün, Afanasiy Nikitin’in gezi yazılarından oluşan ve Türkçeye $\ddot{U} c ̧$ Deniz Ötesine Seyahat olarak çevrilen eserde yer aldığı sözlük yazarı tarafından belirtilmektedir.

\section{АлмАвъ - $\ddot{\varnothing} \alpha \mu \alpha €$, драгоцбонный камень алмазт: - Алмазъ же родится въ горь каменои, а цродають же тую гору каменую локоть по дв потыхъ. Аөан. Никит.}

Türk dillerinden Rusçaya geçen başka bir sözcük olarak “ambar” madde başı анбаръ/амбаръ anbar/ambar, "suyun üzerine, Onega nehri üzerine kurulan duvar boyu yedi kulaç, eni beş kulaç uzunluğunda olan yer" olarak Sreznevskiy'in sözlüğünde tanımlanmaktadır. Bu sözcük Farsçadan Arapçaya da geçmiştir (Fasmer, 1986: 75). Sreznevskiy'in sözlüğünde Eski Rusçada “onbar” olarak da bulunduğu gösterilmekte, 1544 yılına ait Kupçaya Kirillova adlı kaynakta geçtiği belirtilmektedir.

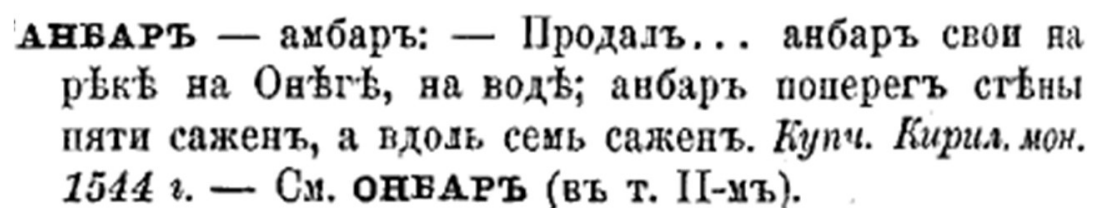

Türk dillerinden Eski Rusçaya geçerek çağdaş Rusçada da varlı̆̆ını sürdüren "belirli bir şeyin satıldı̆̆ yer" anlamındaki "pazar”, базаръ - bazar sözcüğ̈̈ de Sreznevskiy’in sözlüğünde yer almaktadır. Eserde "pazar" madde başının Latince karşılığı sunulmaktadır. "Pazar" sözcüğü İbrani bir peygamber olarak kabul edilen Ezekiel'e ait "pazarlarda ve büyük kutlamalarda” cümlesiyle tanıklanmaktadır. Bununla birlikte XV. yüzyılda Bazarovıh neslinin ünlü olduğu belirtilerek o dönemin soyadlarına ilişkin bilgi de verilmektedir. Böylece Sreznevskiy’in sözlüğü için adbilimle ilgili çalışmalarda bulunduğu açıktır. "Pazar" sözcügünün N. M. Karamzin'in Rusya Devleti Tarihi (İstoriya gosudarstva Rossiyskogo) adlı eserinde geçtiği de sözlükte belirtilmektedir.

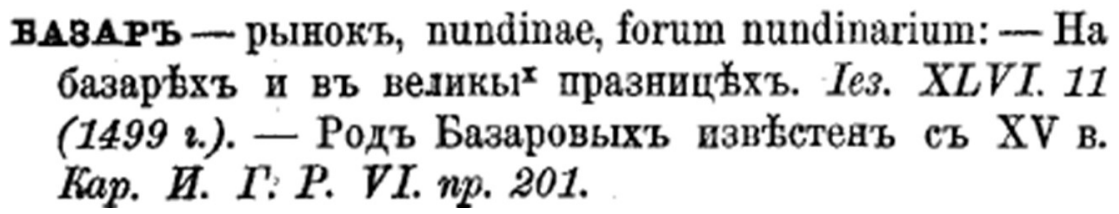

Sreznevskiy, “cami” anlamını taşıyan мечеть - meçet sözcüğünü sözlüğünde 3 ayrı madde başı altında, Eski Rusçada мизгать, мизгить, мезгить - mizgat, mizgit, mezgit olarak göstermiştir. Eski Rusçada мизгить - mizgit sözcüğü Fasmer’in (1986, 613) de belirttiği üzere Arapça ve Türkiye Türkçesinde "mescid", Tatarcada "mäčit" olarak yer almaktadır. Eski Rusçaya geçen "mescid" sözcüğü ses değişimine uğrayarak мечеть - meçet şeklinde Rusçaya alıntılanmış olup günümüz Rusçasında da bu şekliyle korunmaktadır. Sreznevskiy, sözcüklerin geçtiği kaynağı ve tarihi sözlüğünde yine belirtmiştir. 


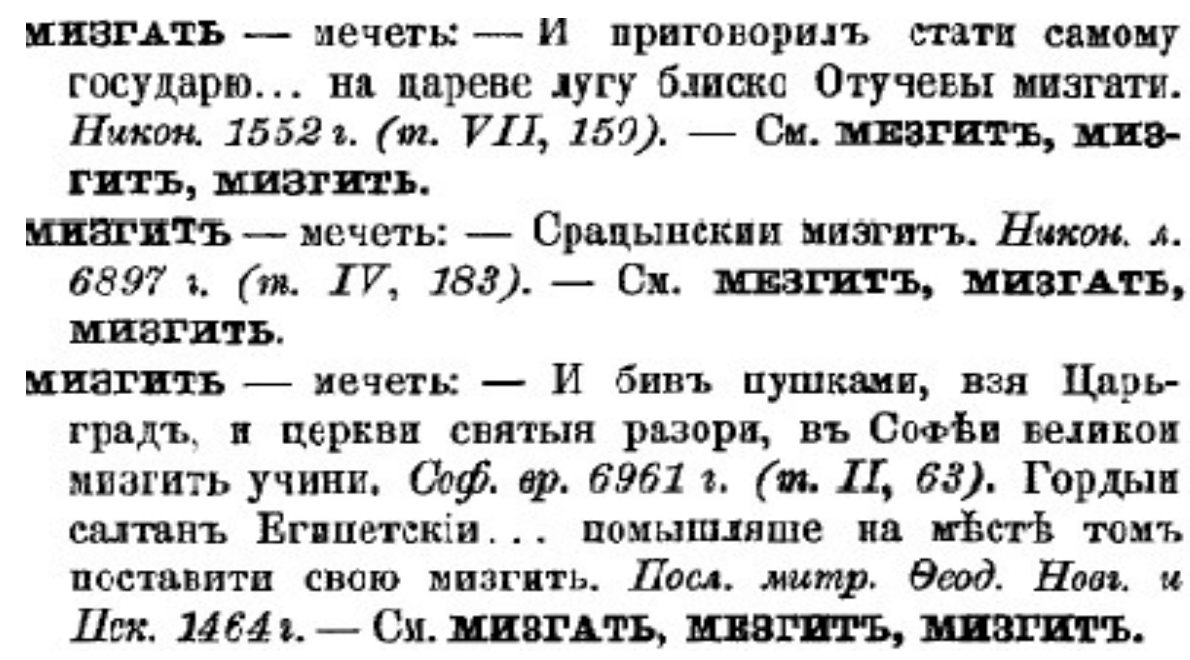

Eski Rusçaya Türk dillerinden geçtiği Fasmer $(1987,48)$ tarafindan belirtilen bir diğer sözcük olarak "ter çekmeye yarayan her türlü terlik giysi, kumaş, takke" anlamında da kullanılan "terlik" терликт - terlik madde başı da Sreznevskiy'in sözlüğünde yer almaktadır. Sreznevskiy "terlik" sözcügünün ilk olarak 1486 yll civarında Vosem duşeunı gramot adlı kaynakta Moskova'da bulunan MojayskVereyskiy bölgesinin Kinyazı tarafından kullanıldığını belirtmiştir. Sreznevskiy’in sözlüğünde kullanılan madde başlarının açılamalarında verilen kaynakların kronolojik bir sıralama takip ettiğini yukarıda belirtmiştik. Aşağıda verilen madde başı da bunun en güzel örneğidir. "Terlik" sözcüğünün ilk olarak 1486, ardından 1525, 1579 ve son olarak 1583-1584 tarihlerine ait kaynaklarda geçtiği sözlükte gösterilmektedir. Sreznevskiy, "terlik” sözcüğünü “dar, içe giyilen kaftan, ipek kumaştan yapılan düğmeli kürk terliği, terlik, takke” olarak tanımlamıştır. Türk dillerinin hazinesi olan Divanü Lügat-it Türk'te (I, 476) de "terlik" madde başı "teri emmek için eğerin veya palanın altına konan keçe" olarak açıklanmıştır. Bu bilgiler ışı̆̆ında kaftan, atkı, kürk, çizme gibi giyilen her türlü malzeme için "terlik" sözcüğünün kullanıldığı anlaşılmaktadır. Bununla birlikte "terlik" madde başında Tatarcasının терлик - terlik, Farsçasının тирлик=дирлик - tirlik=dirlik olduğu bilgisi de okuyuculara sunulmuştur.

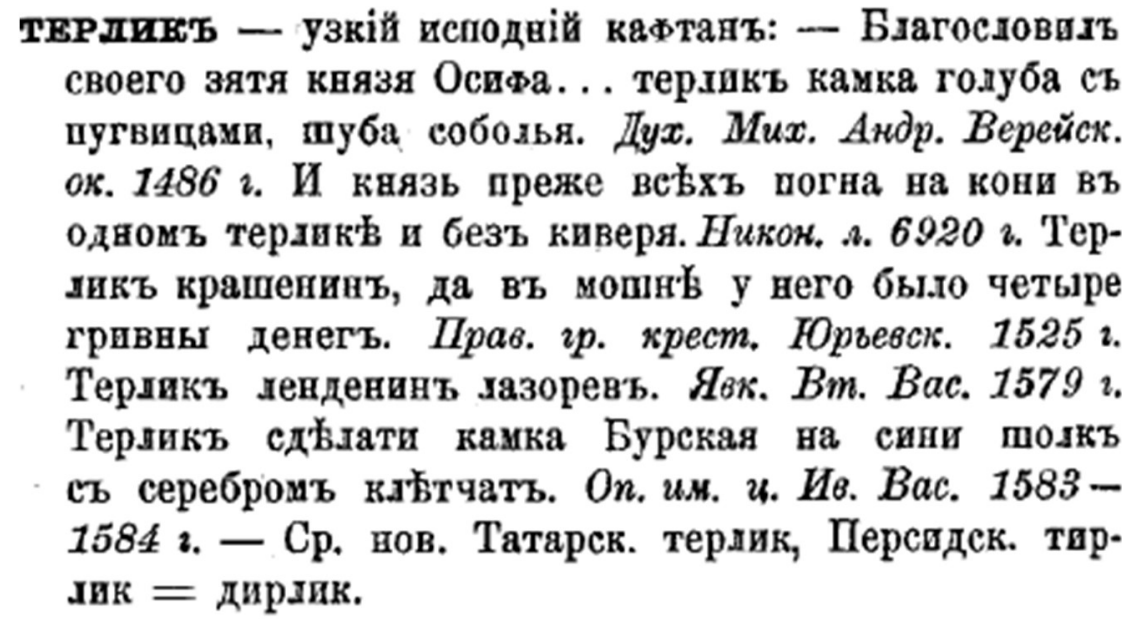
уик $=$ дирлик. 


\section{Sonuç}

Siyaset biliminden dilbilime uzanan yaşamında İzmail İvanoviç Sreznevskiy Rusçanın ilk tarihi sözlüğünü hazırlayarak tarihsel sözlükbilime adını altın harflerle yazdırmıştır. Sreznevskiy'in sözlüğünde XI. ve XV. yüzyıl Eski Rusçaya ait sözcükler temel alınmakla birlikte XI. yüzyıldan XVIII. yüzyıla kadar çok sayıdaki farklı kaynak ve belge türü taranmıştır. Sreznevskiy’in sözlüğünün incelendiği kısımdaki örneklere bakıldığında Türk dillerinden kadim Rusçaya sözcüklerin geçtiği açıktır. Biz bu makalede Türkçeden Rusçaya geçen birkaç kelimeyi inceleyebildik. Bilindiği üzere XI-XII. yüzylllardan itibaren Ruslar ve Türkler Deşt-i Kıpçak denilen sahada birlikte yaşamışlardır. XV. yüzyılın başından itibaren Moskova'da da Rus-Slav toplumunun Türklerle yaşadığını, Türk dilinin genişleyen bir alanda kullanıldığını, Kremlin duvarlarının arkasında yüzyıllar boyu bu iki dille iletişime geçildiğini coğrafyacı, araştırmacı Kupçak kökenli Murat Adji ifade etmiştir (Adji, 2001: 272). Ruslar ve Türkler ticaret, siyaset, evlilik gibi birçok konuda etkileşime girmişlerdir. Dolayısıyla Eski Rusçada Türk kökenli sözcüklerin olması kaçınılmazdır. Bu bağlamda Sreznevskiy’in sözlüğü Ruslar ve Türkler arasındaki kültür, dil, tarih yönünden çeşitli benzerliklerin, ortak yönlerin, vs. ortaya çıkarılması bakımından Türkologlar için zengin bir kaynak imkânı sağlamaktadır. Türkologların incelemesi gereken değerli bir yapıttır. Sözlüğün ikinci baskısı 1957, üçüncü baskısı 1987 yılında yayımlanmıştır. Kendisinden sonraki sözlüklere de kaynaklık eden bu eserden, şimdiye kadar 31 cildi yayımlanmış olan XI-XVII. Yüzyılların Rusça Sözlüğü (Slovar russkogo yazıka XI-XVII) adlı çalışmada da bolca yararlanılmıştır.

Sreznevskiy, Yazılı Eserler Temelinde Eski Rusçamın Sözlüğü İ̧̧in Malzemeler başlıklı eseriyle Rus sözlükbiliminin ilk tarihsel sözlüğ̈nü hazırlayarak kadim Rus toplumunun dilini, kültürünü, toplumsal yaşamını sunan değerli bir kaynağı miras bırakmıştır. Siyasetten Slavistliğe uzanan hayatında bilim ve ailesi öncelikleri olmuştur. Rus dili tarihinin incelenmesi fikrini çalışmalarında ortaya çıkarmıştır. Kadim Rusça dönemindeki belirsizliklerin çözülmesi için çalışmış, o döneme ait kaynakların incelenmesi gerekliliğini vurgulamıştır. Sreznevskiy hem editör, hem yazar olarak Rus sözlükbilimine büyük katkılar sağlayan değerli bir şahsiyet olup Rus sözlükbilim tarihine damgasını vurmuştur.

\section{Kaynakça}

Adji, M. (2001). Kaybolan Millet. (Deşt-i Kıpçak Medeniyeti) Çev: Zeynep Bağlan Özer. Ankara: Atatürk Kültür Merkezi Başkanlığı Yay.

Bogatova, G. A. (Ed.). (2011). Oteçestvennıye leksikografı XVIII-XX vv. Moskva. Russkaya Panaroma.

Dubiçinskiy, V. V. (2009). Leksikografiya Russkogo Yazıka. Moskva: Nauka, Flinta.

Golovina, N. V. (2007). İstoriçeskiye istoçniki v rabotah İ. İ. Sreznevskogo nad slovarem drevnerusskogo yazıka. İ. İ Sreznevskiy i istoriya Slavyano-Russkoy filologii: Tendentsii v nauke, obrazovanii i kulture. Materialı mejdunarodnoy nauçno praktiçeskoy konferentsii, posvyaşçennoy 195-letiyu so dnya rojdeniya akademika İ. İ. Sreznevskogo, 25-27 maya 2007 goda. Ryzan. 194-196.

Fasmer, M. (1986). Etimologiçeskiy slovar russkogo yazıka. T.1. T.2. 2-oye İzdaniye Moskva: Progress.

Fasmer, M. (1987). Etimologiçeskiy slovar russkogo yazıka. T 3. T. 4. 2-oye İzdaniye. Moskva: Progress.

Kaşgarlı, M. (1985). Divanü Lügat-it Türk, Cilt:1. Besim Atalay (Çev.). Ankara: TDK yay.

Kolguşkina, N. V. (2007). İz rodoslovnoy Sreznevskih. İ. İ Sreznevskiy i istoriya slavyano-russkoy filologii: Tendentsii $\mathrm{v}$ nauke, obrazovanii i kulture. Materialı mejdunarodnoy nauçno praktiçeskoy konferentsii, posvyaşçennoy 195-letiyu so dnya rojdeniya akademika İ. İ. Sreznevskogo, 25-27 maya 2007 goda. Ryzan. 105-113.

Krisin, A. P. (2007). Sovremennıy russkiy yazık. Leksiçeskaya semantika. Leksikologiya. Leksikografiya. 2-oye izdaniye. Moskva: Akademiya. 
Sreznevskiy, İ. İ. (1887). Mıslı ob istorii russkogo yazıka. St. Petersburg.

Sreznevskiy, İ. İ. (T. I. 1893 T. II. 1902. T. III. 1912). Materialı dlya slovarya drevnerusskogo yazıka po pismennım pamyatnikam. St. Petersburg.

Sreznevskiy, İ. İ. (1895). Puteviye pisma İzmaila İvanoviça Sreznevskogo iz slavyanskih zemel 18391842. St. Petersburg.

Sreznevskiy, İ. İ. (1903). Stati o drevnih ruskih letopisyah (1853-1866). St. Petersburg: Tip. Akad. Nauk.

Şimçuk, E. G. (2009). Russkaya leksikografiya. Moskva: Akademiya. 